\title{
Structural Engineering Multiperiod Coating ZrN/MoN
}

\author{
O.V. Sobol'1,*, A.A. Meylekhov¹, V.A. Stolbovoy ${ }^{2}$, A.A. Postelnyk ${ }^{1}$ \\ ${ }^{1}$ National Technical University "Kharkiv Polytechnic Institute», 21, Kyrpychova st., Kharkiv, Ukraine \\ 2 National Science Center Kharkov Institute of Physics and Technology, 1, Akademicheskaya St., 61108 Kharkiv,
} Ukraine

(Received 15 June 2016; published online 03 October 2016)

\begin{abstract}
Using the method of structural engineering by changing the thickness of the layers in a multiperiod $\mathrm{ZrN} / \mathrm{MoN}$ system investigated the effect of the phase-texture state of the crystallites and their size on the hardness of the vacuum-arc coating. Is revealed a determining influence on the formation of $\mathrm{ZrN}$ layers preferential orientation growth [100] axis with a small layer thickness 7-20 nm (the deposition of 3 to 10 seconds). At high layer thickness determines the texture [311] crystallites are $\gamma-\mathrm{Mo}_{2} \mathrm{~N}$ phase formed in the Mo-N layers. Pulsed high-voltage stimulation without changing the type of structural states for different layer thicknesses, leads to partial disorientation texture in thick layers. Hardness of coating with thick $(80 \mathrm{~nm})$ layers is $35-37 \mathrm{GPa}$. In small thickness layers pulse stimulation of atoms motility causes the formation of a planar structure with an average crystallite size of $4-9 \mathrm{~nm}$ in the layers, which is accompanied by increased hardness of up to $44 \mathrm{GPa}$.
\end{abstract}

Keywords: Multilayer coating ZrN/MoN, The thickness of the layers, The bias potential, Structure, Crystallite nanosize, Hardness.

DOI: 10.21272/jnep.8(3).03039

PACS numbers: 52.77.Dq, 81.07.Bc, 61.05.cp, 61.82.Rx, 68.55.jm

\section{INTRODUCTION}

Numerous studies conducted in recent years [1-6] showed that by creating a composite coating of the multi-element nitrides [7-10] or alternating two or more layers of nitrides of transition metals [11-14] can largely improve the functional properties of the surface ( to the greatest extent achieved improvement in the mechanical characteristics).

Among the multilayer systems, the highest mechanical properties compared to single components ( $\mathrm{Ti}$, Al)N/VN [15, 16] and TiN/VN [17-19]. Moreover primarily on the properties of these coatings are influenced by the thickness of the layers [20, 21] (most high properties were obtained when the thickness of the layers in the nanometer range). It is assumed that the basis for such an increase in properties of multilayer systems is retaining (quenching spread) the ability of the interlayer boundaries to crack propagation, and hence a high wear resistance values measured from the $\mathrm{H} / \mathrm{E}$ ratio $[22,23]$. The unique properties and structural states MoN coating in the form of single-layer coatings $[24,25]$, and in multilayer compositions [26-30] in the first instance determined by the possibility fibrewise strain relief [24], which is a very important parameter in the formation of a multilayer composition. On the other hand, in recent years an enhanced interest has been shown by coatings based on $\mathrm{ZrN}$ [31], which is largely due to the high resistance of such coatings to oxidation and radiation resistance.

Therefore, as one of the most promising multilayer systems can be considered MoN/ZrN system, which used a combination of nitride allows a high hardness and wear resistance combined with good resistance to oxidation and other influences in aggressive environments.
The aim of this work was to study the influence of such parameters as the thickness of layers on the phase composition, structure and mechanical properties (hardness) of the coatings deposited at a different negative potential bias supplied to the substrate $\left(-U_{b}\right)$, that provides a difference in energy of the particles deposited.

\section{MODES OF RECEIVING COATINGS AND METHODS OF RESEARCH}

Coatings were obtained by vacuum-arc method on the modernized installation "Bulat-6" [32]. Pressure of working (nitrogen) atmosphere during deposition was $P_{\mathrm{N}}=4 \cdot 10^{-3}$ Torr, the deposition speed was about $2 \mathrm{~nm} / \mathrm{sec}$. Deposition was carried out from two sources (Mo and $\mathrm{Zr}$ ) at a predetermined time delay or continuous rotation fixed on substrates of samples at $8 \mathrm{rev} / \mathrm{min}$.

The deposition process is carried out under the following processing conditions. After the deposition of the first layer the two evaporator turned off, turning the substrate holder by $180^{\circ}$ and again at the same time included both evaporators. The arc current during the deposition was $85 \ldots 90 \mathrm{~A}$, the distance from the evaporator to the substrate $-250 \mathrm{~mm}$, the substrate temperature $\left(T_{s}\right)$ was in the range of $250 \ldots 350{ }^{\circ} \mathrm{C}$.

The total coating thickness was about 10 microns with the hourly time deposition. In the process of deposition on the substrate was fed a constant negative potential value $-U_{b}=-110 \mathrm{~V}$ and $-200 \mathrm{~V}$.

Multilayers nanostructured coatings MoN/ZrN with simultaneous ion implantation in the deposition process deposited when applying for a substrate holder along with a negative constant potential and pulse potential with a pulse duration of $10 \mathrm{~ms}$, repetition frequency of $7 \mathrm{kHz}$ and an amplitude of up to $2 \mathrm{kV}$.

\footnotetext{
*sool@kpi.kharkov.ua
} 
The main advantage of the method of plasma ion implantation and deposition (PBII \& D-method) at twophase synthesis of nanostructures MoN/ZrN is to substantially reduce synthesis temperature (below $200{ }^{\circ} \mathrm{C}$ ), which would block an appreciable diffusion mixing components.

The phase composition, structure and substructural characteristics were investigated by X-ray diffraction (DRON-4) using $\mathrm{Cu}-\mathrm{K}_{\alpha}$-radiation. For monochromatic detected radiation used graphite monochromator, which is installed in the secondary beam (front of the detector). The study of phase composition, structure (texture, substructure) produced by conventional methods by X-ray diffraction by analysis of the position, intensity and shape of the diffraction reflexes profiles [33]. To decrypt diffraction patterns used tables International Centre for Diffraction Data Powder Diffraction File.

Microindentation performed on the installation "Micron-gamma" with a load of up to $F=0,5 \mathrm{~N}$ Berkovich diamond pyramid with an angle of $65^{\circ}$, to automatically perform loading and unloading for 30 seconds.

\section{RESULTS AND DISCUSSION}

Analysis of the morphology of the fracture of multilayer coatings show reasonably good planarity of them (Fig. 1), which is typical for all investigated precipitation regimes.

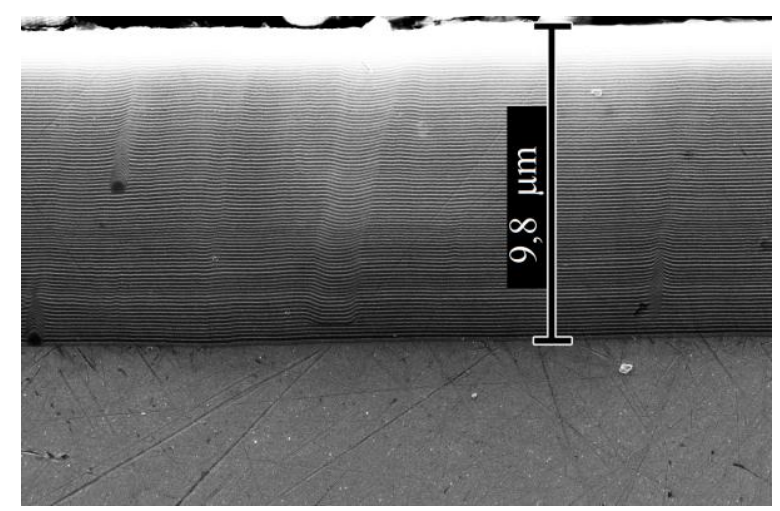

Fig. 1-The lateral cross-section of the multilayer coating with the duration of the overlay layer $\tau=40 \mathrm{sec}$

The phase-structural condition substantially depends on the mode used. Fig. 2 shows plots of the diffraction spectra of coatings deposited at constant $-U_{b}=-110 \mathrm{~V}$ without pulse stimulation rate (Fig. 2a) and the pulse stimulation during growth (Fig. 2b).

One can see that for small time deposited layers (and thus the thickness of layers to $20 \mathrm{~nm}$ ) of the coatings obtained without pulse stimulation (Fig. 2a), there is a change of the preferential orientation of the crystallites on the [100] at the least thickness to [311] at the maximum thickness layers (shown by the arrows of the Fig. 2a). The last occurs simultaneously in both $\mathrm{ZrN}$, MoN and the layers (where this texture is determined by the growth of crystallites $\gamma-\mathrm{Mo} 2 \mathrm{~N}$ phase lattice type $\mathrm{NaCl}$ ). From the analysis of the results of previous studies [24, 30] texture of [311] can be considered in determining these conditions growth in layers $\gamma$-Mo2 $\mathrm{N}$ phase, while for the formation of $\mathrm{ZrN}$ characteristic texture with the [100] or [111].
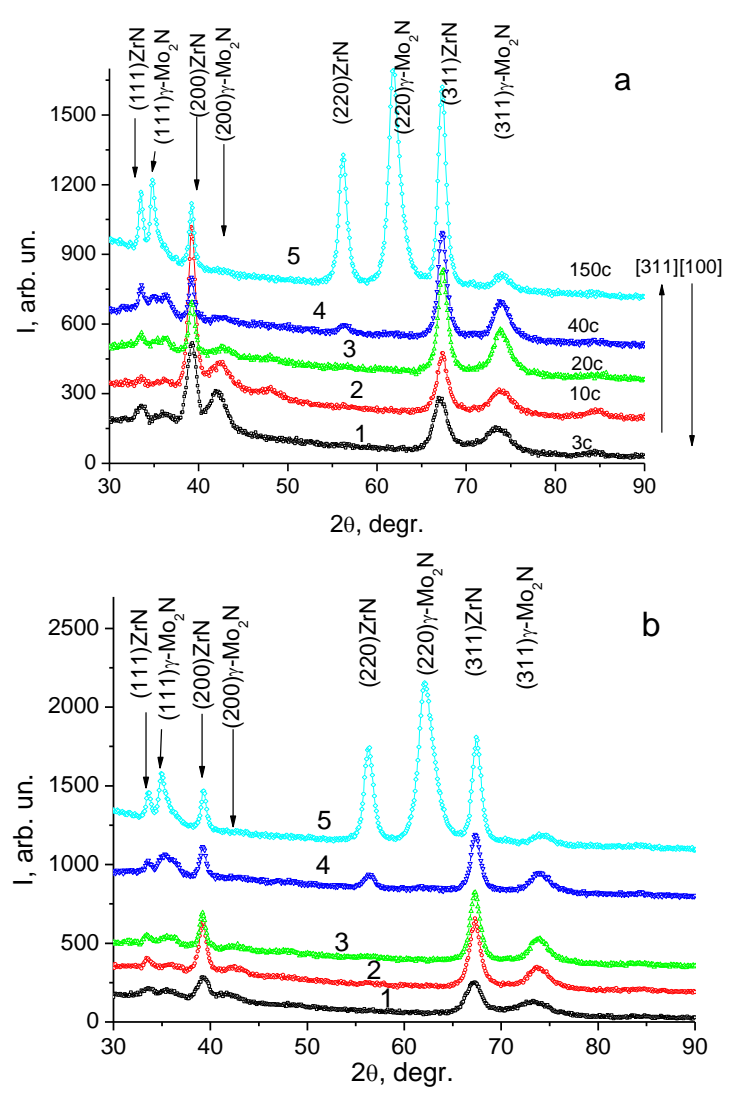

Fig. 2 - Plots diffraction spectra of coatings obtained at a constant potential $-110 \mathrm{~V}$ without bias pulse stimulation (a) and with pulse stimulation (b) when $\tau$, sec.: $1-3,2-10$, $3-20,4-40,5-150$

Therefore, we can assume that at small thicknesses of the layers, specifying the preferred orientation of growth is the texture layers of $\mathrm{ZrN}$ (ie in the layers determines the largest radiation damage due to the heaviest $\mathrm{Zr}$ atoms). With increasing thickness of the layers is determined primarily by the growth of crystallites it becomes a layer of $\gamma \mathrm{Mo} 2 \mathrm{~N}$. This change may be due to the contribution of the growth factors deformation as the thickness of the layers.

If we compare the diffraction spectra of the coatings obtained without pulse stimulation (Fig. 2a) and with pulse stimulation (Fig. 2b), we see that if the general trend of pulse high impact results in greater disorientation of crystallites growth axes, reducing the degree of texturing, and at most to the thickness translates texture characteristic radiation factor action (with [110] axis perpendicular to the growth plane) [7].

This increase in the permanent capacity to $-U_{b}=-200 \mathrm{~V}$ at least thin layers of a thickness of about $7 \mathrm{~nm}(\tau=3 \mathrm{sec})$ leads to increased texture [100] axis, which can be associated with an increase in the mobility of atoms. The latter is a consequence of the increase in the average energy of film-forming charged particles with increasing $-U_{b}$ to $-200 \mathrm{~V}$.

The analysis of crystallite sizes carried out on the broadening of the diffraction reflexes showed that $\mathrm{ZrN}$ layers crystallites have a greater dimension in the direction of growth with increasing deposition time (thickness) of layers from 3 to 150 seconds, a crystallite size $(L)$ is increased by 7 to $15 \mathrm{~nm}$. The crystallite size 
in the layers of $\gamma-\mathrm{Mo}_{2} \mathrm{~N}$ considerably smaller and varies in the range of 3.1-4.5 $\mathrm{nm}$ (Fig. 3, the dependence of 1 and 2). A lower value of the average crystallite size of $\gamma-\mathrm{Mo}_{2} \mathrm{~N}$ phase may be associated with a tendency to its shear deformation due to the relatively low power communication Mo-N (and, accordingly, the heat of formation).

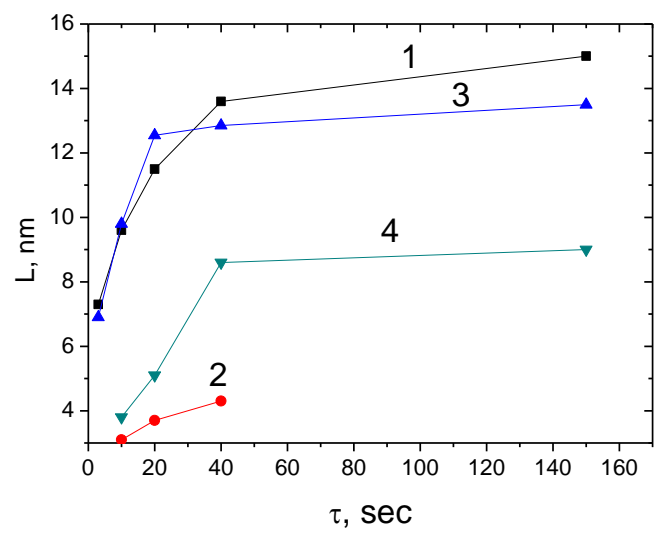

Fig. 3-Changing the size of crystallites in the layers, depending on the deposition time: $1-\mathrm{ZrN}$ (without pulse stimulation) $2-\mathrm{Mo}_{2} \mathrm{~N}$ (without pulse stimulation), $3-\mathrm{ZrN}$ (pulse stimulation), $4-\mathrm{Mo}_{2} \mathrm{~N}$ (pulse stimulation)

Additional pulse stimulation is not a determining effect on the growth of $\mathrm{ZrN}$ crystallites (Fig 3, the dependence 3). But due to increasing mobility significantly increases the average size in the $\gamma-\mathrm{Mo}_{2} \mathrm{~N}$ layers (4 to $8.5 \mathrm{~nm}$ ) with an increase of 3 to $\tau 150 \mathrm{sec}$ (Fig. 3, 4 dependent).

Possibilities of structural engineering on different layers of preferential orientation of the crystallites and their size would greatly change the mechanical properties of multilayer $\mathrm{ZrN} / \mathrm{MoN}$ coating. The most universal criterion of the mechanical characteristics refers the working surface microhardness. Fig. 4 shows the generalized results Microindentation. One can see that increasing $-U_{b}$ to $-200 \mathrm{~V}$, while a strong texture formation stimulated with [100] axis, but leads to a drop in the hardness of the system up to $30 \mathrm{GPa}$.

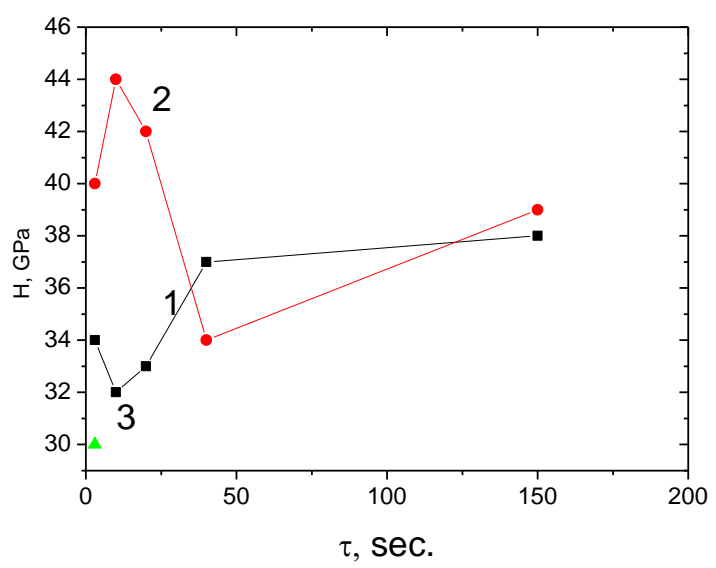

Fig. 4 - Dependence of change microhardness of the coatings at the time of deposition of layers: $1--U_{b}=-110 \mathrm{~V}$, without pulse stimulation, $2--U_{b}=-110 \mathrm{~V}$, with a pulse stimulation, $3--U_{b}=-200 \mathrm{~V}$, with a pulse stimulation

The hardness of coatings obtained by $-U_{b}=-110 \mathrm{~V}$ without pulse stimulating nonuniformly varies in the range of $32-34 \mathrm{GPa}$ at a low layer thickness, with a further increase to $37 \mathrm{GPa}$ with an increase in the average crystallite size of $10 \mathrm{~nm}$ and a perfect texture growth axis [311]. The hardness of such coatings do not significantly change with the greatest layer thickness (about $300 \mathrm{~nm}$ ) and education bitextural state with axes [311] and [110]. In the coatings obtained by $-U_{b}=-110 \mathrm{~V}$ and pulse stimulation of the mobility by potential to $2 \mathrm{kV}$, a hardness similar to that of thick layers of coatings obtained without stimulation and is 35-37 GPa. With a relatively small thickness layers stimulation pulse due to increased mobility of the atoms at their deposition leads to an increase of hardness up to $44 \mathrm{GPa}$, apparently due to the growth with the planarity of the interlayer boundaries and formation of texture with the axis [311].

\title{
Структурна інженерія багатоперіодних покриттів ZrN/MoN
}

\author{
О.В. Соболь ${ }^{1}$, А.О. Мейлехов ${ }^{1}$, В.А. Столбовий${ }^{2}$ Г.О. Постельник ${ }^{1}$
}

\author{
${ }^{1}$ НТУ "Харківський політехнічний інститут», вул. Кирпичова, 21, 61002 Харків, Украӥна \\ ${ }^{2}$ ННЦ “Харківський фбізико-технічний інститут», вул. Акаделічна, 1, 61108 Харків, Україна
}

Використовуючи метод структурної інженерії шляхом зміни товщини шарів в багатоперіодній системі ZrN/MoN досліджено вплив фазово-текстурного стану кристалітів і їх розмір на твердість вакуумно-дугових покриттів. Виявлено визначальний вплив $\mathrm{ZrN}$ шарів на формування переважної оріентації зросту з віссю [100] при малій товщині шарів 7-20 нм (час осадження 3 -10 сек). При великій товщині шарів визначальним текстуру [311] е кристаліти $\gamma$-Mo2 $\mathrm{N}$ фази, що формуеться в Мо-N шарах. Імпульсна високовольтна стимуляція не змінюючи тип структурних станів для різних товщин шарів, призводить до часткової разорієнтації текстури при великій товщині шарів. Твердість покриттів з товстими (80 нм) шарами становить 35-37 ГПа. У шарах малої товщини імпульсна стимуляції рухливості атомів призводить до формування планарної структури з середнім розміром кристалітів в шарах 4-9 нм, що супроводжуеться підвищенням твердості до 44 ГПа.

Ключевые слова: Багатошарові покриття ZrN/MoN, Товщина шарів, Потенщіал зсуву, Структура, Нанорозмір кристалітів, Твердість. 


\title{
Структурная инженерия многопериодных покрытий ZrN/MoN
}

\author{
О.В. Соболь ${ }^{1}$, А.А. Мейлехов ${ }^{1}$, В.А. Столбовой, А.А. Постельник ${ }^{1}$ \\ ${ }^{1}$ НТУ "Харьковский политехнический институт», ул. Кирпичева, 21, 61002 Харьков, Украина \\ ${ }^{2}$ ННЦ "Харьковский фбизико-технический институт», ул. Акаделическая, 1, 61108 Харьков, Украина
}

\begin{abstract}
Используя метода структурной инженерии путем изменения толщины слоев в многопериодной системе ZrN/MoN исследовано влияния фазово-текстурного состояния кристаллитов и их размера на твердость вакуумно-дуговых покрытий. Выявлено определяющее влияние $\mathrm{ZrN}$ слоев на формирование преимущественной ориентации роста с осью [100] при малой толщине слоев 7-20 нм (время осаждения 3 -10 сек). При большой толшине слоев определяющим текстуру [311] являются кристаллиты $\gamma$-Mo2 $\mathrm{N}$ фазы, формируемой в Мо-N слоях. Импульсная высоковольтная стимуляция не меняя тип структурных состояний для разных толщин слоев, приводит к частичной разориентации текстуры при большой толщине слоев. Твердость покрытий с толстыми (80 нм) слоями составляет 35-37 ГПа. В слоях малой толщины импульсная стимулящии подвижности атомов приводит к формированию планарной структуры со средним размером кристаллитов в слоях 4-9 нм, что сопровождается повышением твердости до 44 ГПа.
\end{abstract}

Ключевые слова: Многослойное покрытие $\mathrm{ZrN} / \mathrm{MoN}$, Толщина слоев, Потенщиал смещения, Структура, Наноразмер кристаллитов, Твердость.

\section{REFERENCES}

1. N. Ghafoor, I. Petrov, D. Klenov, B. Freitag, J. Jensen, J.E. Greene, L. Hultman, M. Odén, Acta Materialia 82, 179 (2015).

2. O.V. Sobol', Phys. Solid State 49 No 6, 1161 (2007).

3. C. Sabitzer, J. Paulitsch, S. Kolozsvári, R. Rachbauer, P.H. Mayrhofer, Thin Solid Films 610, 26 (2016).

4. E. Mohammadpour, Zh.-T. Jiang, M. Altaraneh, Z. Xie, Zh.-F. Zhou, N. Mondinos, J. Kimpton, B.Z. Dlugogorski, Thin Solid Films 599, 98 (2016).

5. H.-Li Huang, Y.-Yu Chang, J.-Xu Liu, M.-Tzu Tsai, Ch.-Ho Lai, Thin Solid Films 596, 111 (2015).

6. P. Dubey, V. Arya, S. Srivastava, D. Singh, R. Chandra, Surf. Coat. Technol. 284, 173 (2015).

7. N.A. Azarenkov, O.V. Sobol, A.D. Pogrebnyak, I.N. Toryanik, Metallof. Nov. Tekhnol. 35 No 8, 1061 (2013).

8. D.G. Sangiovanni, L. Hultman, V. Chirita, I. Petrov, J.E. Greene, Acta Materialia 103, 823 (2016).

9. Z.T. Wu, Z.B. Qi, D.F. Zhang, Z.C. Wang, Surf. Coat. Technol. 276, 219 (2015)

10. S.A. Glatz, R. Hollerweger, P. Polcik, R. Rachbauer, J. Paulitsch, P.H. Mayrhofer, Surf. Coat. Technol. 266, 1 (2015).

11. H. Wang, H. Zeng, Q. Li, J. Shen, Thin Solid Films 607, 59 (2016).

12. J. Perne, Thin Solid Films 573, 33 (2014).

13. K. Bobzin, T. Brögelmann, R.H. Brugnara, N.C. Kruppe, Surf. Coat. Technol. 284, 222 (2015).

14. Y.X. Ou, J. Lin, H.L. Che, W.D. Sproul, J.J. Moore, M.K. Lei, Surf. Coat. Technol. 276, 152 (2015).

15. R. Ananthakumar, B. Subramanian, A. Kobayashi, M. Jayachandran, Ceram. Int. 38 No 1, 477 (2012).

16. Ch.-L. Liang, G.-An Cheng, R.-T. Zheng, H.-P. Liu, Thin Solid Films $\mathbf{5 2 0}$ No 2, 813 (2011).

17. B. Subramanian, R. Ananthakumar, A. Kobayashi, M. Jayachandran, J. Mater. Sci.: Mater. Medicine 23 No 2 , 329 (2012).

18. U. Helmersson, S. Todorova, S.A. Barnett, J.-E. Sundgren, L.C. Markert, J. Appl. Phys. 62, 481 (1987).
19. M.E. Uslu, A.C. Onel, G. Ekinci, B. Toydemir, S. Durdu, M. Usta, L.C. Arslan, Surf. Coat. Technol. 284, 252 (2015).

20. M. Pfeiler-Deutschmann, M.P. Heinz, K. Chladil, M. Penoy, C. Michotte, M. Kathrein, C. Mitterer, Thin Solid Films 581, 20 (2015).

21. M.K. Samani, X.Z. Ding, N. Khosravian, B. Amin-Ahmadi, Yang Yi, G. Chen, E.C. Neyts, A. Bogaerts, B.K. Tay, Thin Solid Films 578, 133 (2015).

22. F.F. Klimashin, H. Riedl, D. Primetzhofer, J. Paulitsch, P.H. Mayrhofer, J. Appl. Phys. 118, 025305 (2015).

23. F.F. Klimashin, H. Euchner, P.H. Mayrhofer, Acta Materialia 107, 273 (2016).

24. H.-K. Kim, J.-H. La, K.-S. Kim, S.-Y. Lee, Surf. Coat. Technol. 284, 230 (2015).

25. O.V. Sobol', A.A. Andreev, V.A. Stolbovoi, V.E. Fil'chikov, Tech. Phys. Lett. +38 No 2, 168 (2012)

26. A. Gilewicz, R. Jedrzejewski, A.E. Kochmanska, B. Warcholinski, Thin Solid Films 577, 94 (2015).

27. M.I. Yousaf, V.O. Pelenovich, B. Yang, C.S. Liu, D.J. Fu, Surf. Coat. Technol. 282, 94 (2015).

28. A. Gilewicz, B. Warcholinski, Surf. Coat. Technol. 279, 126 (2015).

29. M.I. Yousaf, V.O. Pelenovich, B. Yang, C.S. Liu, D.J. Fu, Surf. Coat. Technol. 265, 117 (2015).

30. G. Zhang, T. Wang, H. Chen, Surf. Coat. Technol. 261, 156 (2015).

31. V.M. Beresnev, O.V. Sobol, $\quad$ A.V. Stolbovoy, S.V. Litovchenko, D.A. Kolesnikov, U.S. Nemchenko, A.A. Meylehov, A.A. Postelnik, J. Nano- Electron. Phys. 8 No 1, 01043 (2016).

32. O.V. Sobol, A.A. Andreev, V.F. Gorban, A.A. Meylehov, A.A. Postelnik, V.A. Stolbovoy, J. Nano- Electron. Phys. 8, No 1, 01042 (2016).

33. O.V. Sobol', A.A. Andreev, S.N. Grigoriev, V.F. Gorban' M.A. Volosova, S.V. Aleshin, V.A. Stolbovoi, Metal Sci. Heat Treatm. 54 No 3-4, 195 (2012).

34. O.V. Sobol', A.A. Andreev, S.N. Grigoriev, V.F. Gorban', S.N. Volosova, S.V. Aleshin, V.A. Stolbovoy, Problem. Atomic Sci. Technol. No 4(74), 174 (2011). 